\title{
Induction of Galanin mRNA in GnRH Neurons by Estradiol and its Facilitation by Progesterone
}

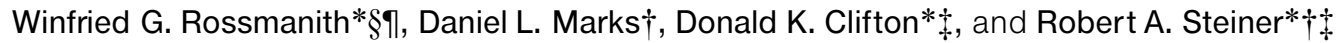 \\ *Departments of Obstetrics-Gynecology, †Physiology and Biophysics, †the Population Center for Research in Reproduction, \\ University of Washington, Seattle, Washington 98195, USA. \\ §Department of Obstetrics and Gynecology, University of UIm, D-89075 UIm, Germany.
}

Key words: galanin mRNA, gonadotropin-releasing hormone $(\mathrm{GnRH})$ estradiol, progesterone, hypothalamus, in situ hybridization.

\begin{abstract}
On the day of proestrus in the rat, rising plasma levels of estradiol $(E)$ act in concert with progesterone $(P)$ to trigger a preovulatory release of gonadotropins. Cellular levels of galanin mRNA in GnRH neurons are increased in association with the proestrous surge of gonadotropin secretion; however, the relative contribution made by $\mathrm{E}$ and $\mathrm{P}$ to the induction of galanin mRNA expression in GnRH neurons is unknown. We investigated the role of $E$ and $P$ in the induction of galanin gene expression in $\mathrm{GnRH}$ neurons by examining the effects of different combinations of $\mathrm{E}$ (estradiol benzoate; $50 \mu \mathrm{g}$ and $\mathrm{P}(5 \mathrm{mg})$ ) on the LH surge and the concomitant induction of galanin mRNA in GnRH neurons. We sacrificed ovariectomized adult rats after 1 of 4 treatments: Group 1: vehicle control $(n=6)$; $G$ roup 2: $P$ alone $(n=$ 7) Group 3: E alone $(n=7)$; Group 4: combined E/P $(n=6)$; the animals were killed at $18.00 \mathrm{~h}$ at the time of the LH surge. The brains from these animals were processed by double-label in situ hybridization to allow measurement of galanin mRNA levels in GnRH neurons. GnRH neurons were identified with a digoxigenin-labeled cRNA probe for GnRH mRNA, and galanin mRNA was detected and measured simultaneously with an ${ }^{35} \mathrm{~S}$-labeled cRNA probe coupled with computerized grain counting. Estimation of cellular levels of GnRH mRNA was accomplished with single-label in situ hybridization, an ${ }^{35} \mathrm{~S}$-labeled GnRH cRNA probe and computerized grain counting. We observed a 3-fold induction of galanin mRNA in the GnRH neurons of animals treated with $E$ alone compared with those treated with the vehicle alone (vehicle: $13 \pm 2$ vs E: $42 \pm 4$ grains/cell $(\mathrm{g} / \mathrm{c}$ ); $\mathrm{P}<0.01$ ); $\mathrm{LH}$ levels in the E-treated animals were elevated, albeit moderately, with respect to the vehicle controls. Compared with vehicle-treated animals, those treated with the combination of $E$ and $P$ showed a 5-fold induction of galanin mRNA in GnRH neurons $(68 \pm 9 \mathrm{~g} / \mathrm{c})$, which was significantly $(P<0.01)$ greater than that observed in the animals treated with $\mathrm{E}$ alone; in addition, the magnitude of the LH surge was much greater $(\mathrm{P}<0.05)$ in the E/P-treated group compared with the $E$ alone group. In contrast, compared to the vehicle controls, animals treated with $P$ alone $(15 \pm 2 \mathrm{~g} / \mathrm{c})$ showed no discernable effect on galanin mRNA levels; moreover, no LH surge occurred in the P alone group. Neither the number of identified GnRH cells nor their content of GnRH mRNA differed significantly among the experimental groups (GnRH mRNA signal: vehicle controls: $153 \pm 6$ vs E: $159 \pm 6$ vs E/P: $153 \pm 3$ vs $P: 148 \pm 8 \mathrm{~g} / \mathrm{c}$ ). We conclude that while $E$ is the primary ovarian signal inducing galanin mRNA expression in GnRH neurons and the LH surge itself, P plays a facilitatory role in both of these processes.
\end{abstract}

In the rat, beginning on the day of diestrus and continuing through proestrus, a rising tide of estradiol (E) serves as the proximate signal eliciting the preovulatory surge of LH (see (1) for review). Progesterone (P) facilitates the action of $\mathrm{E}$ by enhancing the magnitude of the LH surge and honing its occurrence to a narrow window of time during the late afternoon and early evening hours of proestrus. The targets for the action of these sex steroids include neurons in the hypothalamus and forebrain, which transduce the steroid signals and relay them to gonadotropin-releasing hormone (GnRH) neurons (2). In response, GnRH neurons become activated and secrete GnRH, thus serving as the final common pathway through which the brain initiates and supports the preovulatory surge of gonadotro- pin secretion $(3,4)$. While the basic endocrine aspects of this so-called positive feedback event have been carefully defined over the past 50 years, the molecular and cellular underpinnings of the process are less well understood and are currently the subject of detailed investigation.

A strong case can be made for the concept that galanin plays a critical role in the ability of GnRH neurons to generate the preovulatory surge of gonadotropins. First, galanin is colocalized in a subset of GnRH neurons that are either identical to or reside nearby GnRH neurons that become transcriptionally activated during proestrus $(5,6)$. Second, galanin mRNA and galanin peptide in GnRH neurons are induced in association the proestrous LH surge $(7,8)$. Third, galanin administered into the cerebral

Correspondence to: Robert A. Steiner, Department of Physiology \& Biophysics, SJ-40 University of Washington, Seattle, WA 98195 USA. IPermanent address: Department of Obstetrics-Gynecology, University of Ulm, Prittwitzstrasse 43, D-89075 Ulm, Germany.

(C) 1996 Blackwell Science Ltd 
ventricles stimulates the release of $\mathrm{LH}$ through a mechanism that may involve the release of GnRH $(9,10)$, and fourth, pharmacological blockade of galanin's action on proestrus inhibits the proestrous-induced LH surge $(11,12)$. Together, these observations attest to the functional significance of galanin in the neuroendocrine reproductive axis but leave unresolved many aspects of its regulation by steroid hormones.

One unresolved problem is defining the relative role of $\mathrm{E}$ and $\mathrm{P}$ in the induction of galanin expression in GnRH neurons during the proestrous surge of $\mathrm{LH}$. We know that treatment of ovariectomized rats with a combined regimen of $\mathrm{E}$ and $\mathrm{P}$ elicits both an LH surge and induces the expression of galanin mRNA in GnRH neurons (13); however, the relative contributions of the two sex steroids to galanin induction is unknown. We tested the hypothesis that $\mathrm{P}$ facilitates the action of $\mathrm{E}$ on galanin gene expression in GnRH neurons. Using double-label in situ hybridization and computerized imaging, we compared levels in galanin mRNA in GnRH neurons in groups of ovariectomized female rats treated with $\mathrm{E}$ alone, $\mathrm{P}$ alone, or a combined regimen of $\mathrm{E}$ and $\mathrm{P}$ and report that $\mathrm{P}$ facilitates the E-induced increase in galanin mRNA in GnRH neurons.

\section{Results}

\section{Serum LH levels}

Serum LH concentrations for all experimental groups are displayed in Table 1. In the vehicle-treated animals, serum levels of LH were within the normal range for ovariectomized rats. In animals treated with $\mathrm{E}$ alone, serum levels of $\mathrm{LH}$ were increased by $40 \%$ compared to vehicle-treated controls, indicating the presence of an LH surge. [LH levels would have been suppressed by E treatment if an LH surge had not occurred (14).] In animals treated with $\mathrm{P}$ alone, $\mathrm{LH}$ levels were similar to those in the vehicle-treated group; this observation is consistent with previous reports that $\mathrm{P}$ alone does not affect $\mathrm{LH}$ secretion in ovx rats (15). Treatment with the combined $\mathrm{E} / \mathrm{P}$ regimen induced a nearly 3 -fold increase serum LH levels in 6 of the 7 animals in this group, which approximated the magnitude of a normal proestrous LH surge. (One animal in this group failed to show the expected LH surge and was excluded from the group by this criteria; however, the brain from this animal was processed for doublelabel in situ hybridization and results of the tissue analysis from this animal is reported in the following section.)

\section{Levels of galanin-mRNA in GnRH neurons}

GnRH-mRNA containing cells could be readily identified in all groups of animals and were shown to be distributed throughout the basal forebrain in a fashion previously well described (16).

TABLE 1. Plasma levels of LH in all Experimental Groups. Details on Treatment Paradigms can be found in the Material and Methods Section. Values are Expressed as Mean \pm SEM.

\begin{tabular}{ll}
\hline & LH $(\mathrm{ng} / \mathrm{ml})$ \\
\hline Vehicle alone $(\mathrm{n}=6)$ & $21 \pm 5$ \\
Progesterone alone $(\mathrm{n}=7)$ & $18 \pm 2$ \\
Estradiol alone $(\mathrm{n}=7)$ & $30 \pm 4$ \\
Estradiol + Progesterone $(\mathrm{n}=6)$ & $56 \pm 15^{*}$ \\
\hline
\end{tabular}

$* \mathrm{P}<0.05$ vs all other groups.

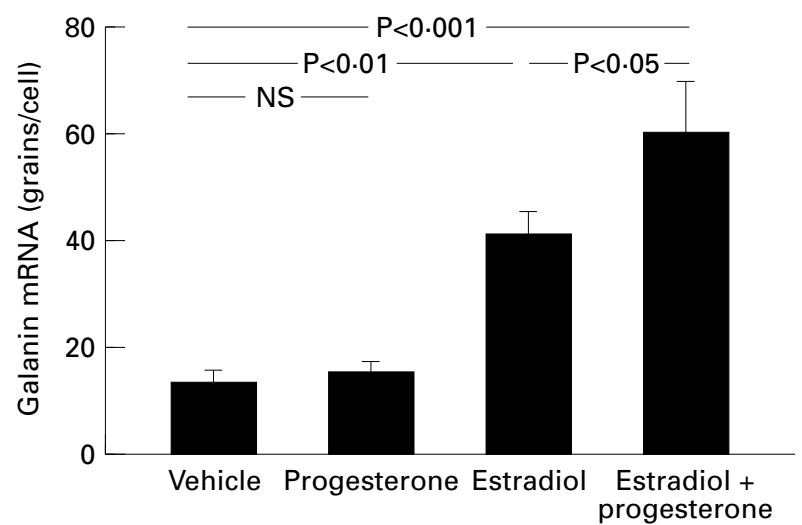

FIG. 1. Relative levels of galanin mRNA signal (grains per cell + SEM) in GnRH neurons throughout the forebrain and rostral hypothalamus in groups of adult ovariectomized rats under different treatment regimens. (Galanin mRNA levels were measured in all GnRH neurons identified on every 4 th section cut throughout the brain.) The 4 groups were vehicletreated animals (controls; $n=6)$, progesterone-treated animals $(n=7)$, estradiol-treated $(n=7)$, and estradiol plus progesterone-treated animals $(n=6)$.

GnRH neurons were clustered in the anterior hypothalamic area (AHA), horizontal and vertical limbs of the diagonal band of Broca (DBBH and DBBV, respectively), the medial preoptic area (MPOA), the median preoptic area (MnPOA), the lateral preoptic area (LPOA), organum vasculosum of the lamina terminalis (OVLT), and the medial septum (MS).

Galanin mRNA in GnRH neurons in vehicle-treated controls was detectable, but uniformly low, in all anatomical areas $(13 \pm 3$ grains/cell; Figs 1 and 2). E increased galanin message levels in GnRH neurons approximately 300\% over that of controls $(\mathrm{P}<0.001$; Figs 1 and 2). The increase in galanin mRNA content was most pronounced in GnRH neurons located in the more caudal section of the DBB and the preoptic area. In contrast to the effect of E, galanin message levels in GnRH neurons of P-treated animals were not significantly different from vehicletreated controls (Figs 1 and 2). However, when $\mathrm{P}$ was combined with E treatment, galanin mRNA content in GnRH neurons was increased by approximately 5 -fold over that of vehicle-treated controls $(\mathrm{P}<0.001$; Fig. 1$)$ and was approximately $40 \%$ higher than in animals receiving E alone (Figs 1 and 2). (In the single animal that did not show a surge-like increase in $\mathrm{LH}$ following E/P treatment, galanin mRNA levels were low ( $\sim 9$ grains/cell) and indistinguishable from those of the vehicle-treated controls.) The overall distribution and intensity of grain clusters representing galanin mRNA in non-GnRH neurons was not subjectively different among the groups. However, it is important to note that galanin is widely expressed in a heterogenous population of neurons throughout the brain, and possibly significant changes in galanin expression within small subsets of this large population would likely be diluted in an analysis lacking a more specific taxonomical criterion, i.e. beyond the fact that they expressed galanin.

\section{GnRH mRNA content in GnRH neurons}

There were no significant differences among the experimental groups in cellular levels of GnRH mRNA, based either on an overall analysis (Fig. 3) or as a function of anatomical location 

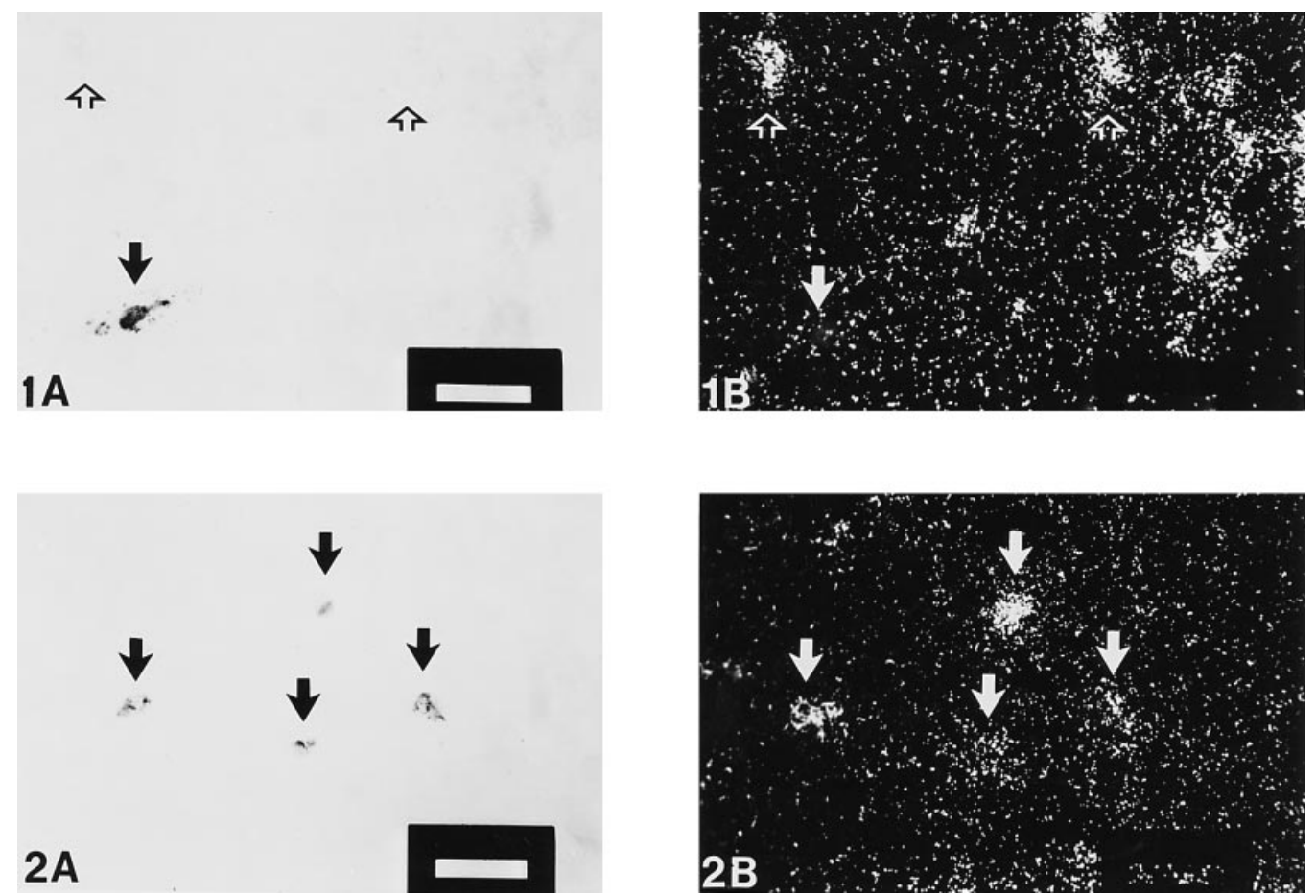

FIG. 2. Panel 1A. A light field photomicrograph of a single GnRH neuron (solid black arrow), containing the digoxigenin-labeled probe for GnRH mRNA, in an animal that received $\mathrm{P}$ alone and that was subsequently killed at $18.00 \mathrm{~h}$. (The open black arrow indicate the position of clusters of silver grains, visible in Panel 1B, indicating the presence of galanin mRNA-containing cells that are not GnRH neurons, i.e. not simultaneously labeled with digoxigenin.) Panel 1B. A dark field photomicrograph of the same view as Panel 1A, showing clusters of silver grains indicating the presence of galanin mRNA-containing cells (open white arrows); these particular cells are not GnRH neurons, indicated by the lack of digoxigenin-label in the same position in Panel 1A (open black arrows). The relative paucity of silver grains over region where the GnRH neuron is visible in Panel 1A (solid white arrow) indicates that this GnRH neurons is coexpressing little or not galanin mRNA. Panel 2A. A light field view of 4 GnRH neurons (black arrows), containing the digoxigenin-labeled probe for GnRH mRNA, in an animal that received the combined E/P treatment regimen and that was subsequently killed at $1800 \mathrm{~h}$ during the induced LH surge. Panel 2B. A dark field photomicrograph of the identical view as Panel $1 \mathrm{~A}$, showing clusters of silver grains indicating the presence of galanin mRNA at the position of the GnRH neurons visible in Panel 2A (solid white arrows). Note the relative abundance of silver grains in each cluster, indicating a relatively high level of galanin expression in these cells. The bar indicates a length of $50 \mathrm{~mm}$.

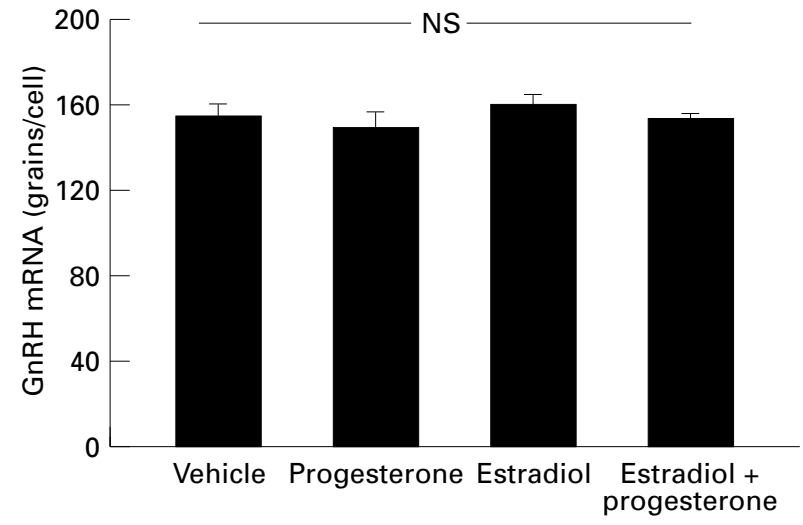

FIG. 3. Relative levels of GnRH mRNA signal (grains per cell + SEM) in GnRH neurons sampled throughout the forebrain and rostral hypothalamus in groups of adult, ovariectomized rats under different treatment regimens. The 4 groups were vehicle-treated animals (controls; $n=6$ ), progesterone-treated animals $(n=7)$, estradiol-treated $(n=7)$, and estradiol plus progesterone-treated animals $(n=6)$. ( $\mathrm{GnRH}$ mRNA levels were measured in all GnRH neurons observed in every 4th section cut throughout the brain. There were no differences among the groups in the number of GnRH neurons identified either overall or as a function of their anatomical location. See text for details.)

(C) 1996 Blackwell Science Ltd, Journal of Neuroendocrinology, 8, 185-191 (data not shown). All GnRH mRNA-containing neurons were counted in every 4 th section cut throughout the brain; the number of GnRH neurons did not differ significantly among the experimental groups (data not shown).

\section{Discussion}

In the present work, we have shown that pharmacological treatment of ovariectomized animals with $\mathrm{E}$ alone induces the expression of galanin mRNA within GnRH neurons and that $\mathrm{P}$ enhances this action, but is ineffective when administered by itself. These observations confirm and extend the earlier report of Brann and his colleagues who demonstrated that total hypothalamic content of galanin mRNA is increased following $\mathrm{E}$ and $\mathrm{P}$ priming of ovariectomized, immature rats (17). The effects of $\mathrm{E}$ and $\mathrm{P}$ on galanin gene expression in GnRH neurons parallel the actions these steroids have on the generation of an LH surge: E induces an LH surge, which is enhanced by $\mathrm{P}$, whereas $\mathrm{P}$ alone is ineffective. We have previously shown that conditions that lead to an LH surge (spontaneous and E/P-evoked) also induce galanin gene expression in GnRH neurons, whereas physiological and pharmacological factors that block the LH surge prevent this induction $(8,13,18,19)$. Taken together, these observations 
underscore the fact that galanin mRNA expression in $\mathrm{GnRH}$ neurons is tightly coupled to the occurrence of an LH surge.

While our results demonstrate a stimulatory effect of $\mathrm{E}$ on galanin in GnRH neurons, the chain of events leading to this effect is still a matter of speculation. It is unlikely that this effect is due to a direct action of $\mathrm{E}$ on GnRH neurons, as these cells do not appear to express the classical E receptor (20). Although it is conceivable that either low levels of $\mathrm{E}$ receptor expression in GnRH neurons have gone undetected or that GnRH neurons express cell surface receptors for (21-23), the weight of evidence suggests that a population of interneurons receives the $\mathrm{E}$ signal and relays this information to GnRH neurons through some unidentified neurotransmitter system(s) (e.g. GABA, (24); NPY, (25). In response to stimulation by the steroid-sensitive interneurons, GnRH neurons become transcriptionally activated, as reflected by the induction of the immediate early gene products, FOS and JUN (26-28). Temporally linked with the appearance of FOS and JUN, cellular levels of galanin mRNA in GnRH neurons are also increased, and anatomical comparisons suggest that it is the identical population of GnRH neurons that expresses both FOS and galanin (8). There are elements on the $5^{\prime}$ flanking region of the galanin gene that have the ability to bind members of the FOS/JUN family of transcription factors $(29,30)$, and it would seem reasonable to infer that upon activation by the steroid-sensitive interneurons, GnRH neurons begin to express the transcription factors, FOS and JUN, which in turn activate these elements on the galanin gene and induce its expression (31).

The action of $\mathrm{P}$ on galanin gene expression may be direct upon the GnRH neurons themselves, since at least in the brain of the guinea pig, a small subset of GnRH neurons expresses the progestin receptor (32). Alternatively, a population of interneurons may receive the $\mathrm{P}$ signal and relay this information indirectly to GnRH neurons (33). Studies in a variety of rodent species have revealed that several distinct populations of hypothalamic neurons express the progestin receptor, including enkephalin-, $\beta$-endorphin-, substance $\mathrm{P}$-, and GABA-containing neurons $(34,35)$. E induces the expression of progestin receptors in the hypothalamus (36), and studies in the guinea pig brain suggest that E-induced progestin receptors are present exclusively in cells that contain $\mathrm{E}$ receptors (37). The failure of $\mathrm{P}$ alone to induce either an LH surge or galanin expression in GnRH neurons may reflect the fact that without $\mathrm{E}$, there can be neither expression of progestin receptor nor initiation of its dependent, down-stream effects.

Based on these collective observations, a plausible working hypothesis can be drawn to explain how ovarian steroids induce galanin gene expression in GnRH neurons. First, at proestrus in the rat, a discrete population of E-sensitive neurons becomes activated in response to $\mathrm{E}$, which in turn induces expression of the progestin receptor in these same cells. With both $\mathrm{E}$ and progestin receptors activated by their respective ligands, these neurons activate GnRH neurons. This activation induces expression of one or more transcription factors, which leads to induction of galanin in GnRH neurons. The fact that pharmacological blockade of synaptic transmission concomitantly blocks the E/Pinduced LH surge, the appearance of FOS, and the induction of galanin mRNA in GnRH neurons lends credence to this postulated sequence $(13,26)$.

Following the induction of galanin gene expression in $\mathrm{GnRH}$ neurons by ovarian steroids, how does galanin participate in the generation of an LH surge? It is conceivable that galanin cosecreted with $\mathrm{GnRH}$ acts at the pituitary to facilitate the action of GnRH (38). There is also indirect evidence to suggest that galanin acts presynaptically on GnRH nerve terminals. First, galanin is capable of stimulating the release of $\mathrm{GnRH}$ from hypothalamic fragments (10), and second, galanin binding sites are densely concentrated in the median eminence (39). Currently, evidence would seem to favor a presynaptic effect of galanin on $\mathrm{GnRH}$ neurons as its primary mode of action, as opposed to acting on a target in the anterior pituitary gland. The reasoning here derives from three observations- one that provides a precedent for galanin acting presynaptically elsewhere in the nervous system and two others that argue against the logic of a pituitary site of action for brain-derived galanin. First, galanin is a cotransmitter with acetylcholine in a septal-hippocampal projection pathway and is thought to act as presynaptically to modulate acetylcholine secretion $(40,41)$. Second, the anterior pituitary itself produces considerable quantities of galanin $(42,43)$, making it difficult to conceive how minute amount of galanin reaching the pituitary from the portal circulation could have a significant impact on pituitary function. Third, at least one other population of hypophysiotropic neurosecretory cells is known to coexpress galanin: growth hormone-releasing hormone (GHRH)-secreting neurons $(44,45)$. Galanin transported in the hypophyseal portal circulation would presumably reflect the combined secretion from both GnRH and GHRH neurons, each with different target cells in the anterior pituitary. Given this fact, it is difficult to conceive how the target cells for GnRH and GHRH, the gonadotrope and somatotrope, respectively, could decipher the source of galanin acting upon them, if indeed they are both target cells for galanin cosecreted the hypophysiotropic neurons. These considerations aside, it is clear that future studies need to identify the site of action for galanin and its physiological significance.

In contrast to the effects of $\mathrm{E}$ and $\mathrm{P}$ on galanin mRNA in GnRH neurons, we could adduce no evidence for sex steroid effects on GnRH gene expression. Neither the number of identifiable GnRH neurons nor the cellular content GnRH mRNA was altered as a function of any experimental manipulation. These results are in accord with previous observations by our laboratory that fail to reveal any significant alterations in cellular levels of GnRH mRNA, despite marked changes in the steroid milieu $(8,13,18,19)$. Our findings with respect to GnRH mRNA remain in contradiction to the earlier reported work of several other laboratories (46-48). A recent report by Petersen and her colleagues suggests that temporal factors and neuroanatomical specialization of the GnRH network may help to reconcile some of the disparate results in the literature (49). Beyond this, we are unable to offer any compelling explanation for these contradictory results, beyond the fact that differences in some aspects of the experimental design between the studies could be the source of the discrepancy. Alternatively, it is conceivable that there is an effect of steroid treatments, but the effect on cellular levels of GnRH mRNA is below the limits of sensitivity of our laboratory's current in situ hybridization methodology. In any case, whatever effect $\mathrm{E}$ and $\mathrm{P}$ may have on cellular levels of GnRH mRNA, it is relatively small compared to the effect of these steroids on galanin mRNA in the same population of GnRH neurons.

In summary, we have shown that $\mathrm{E}$ is capable of stimulating LH secretion and inducing expression of galanin mRNA in $\mathrm{GnRH}$ neurons and that $\mathrm{P}$ facilitates both responses. Although 
the physiological relationship between the LH surge and galanin induction is uncertain, it is clear that these phenomena are temporally and quantitatively linked. Based on these and related studies, we conclude that induction of galanin gene expression in GnRH neurons is a requisite step in the pathway leading to the LH surge in the rat.

\section{Materials and methods}

Animals

Adult (70 day old) female Sprague-Dawley rats were purchased from Simonsen Laboratories (Gilroy, CA, USA). They were housed under pathogen-free, temperature $\left(20^{\circ} \mathrm{C}\right)$ and light-controlled conditions (alternating light-dark cycle with $14 \mathrm{~h}$ light, $10 \mathrm{~h}$ dark, lights on at $07.00 \mathrm{~h}$ ). The animals were given free access to tap water and rat chow. The rats were handled daily for one week prior to ovariectomy and the steroid treatments. Ovariectomy was performed under ether anesthesia and the animals were allowed to pass through 21 days before start of the steroid injections.

\section{Experimental Design}

We tested the hypothesis that $\mathrm{P}$ facilitates the E-induced $\mathrm{LH}$ surge and the expression of galanin mRNA in GnRH neurons. We approached this by administering either $\mathrm{E}$ or $\mathrm{P}$ alone or in combination to chronically ovariectomized rats ( 21 days after ovariectomy). Four groups of ovariectomized rats were used. The first group $(n=6)$ received a subcutaneous (s.c.) injection of peanut oil $(0.2 \mathrm{ml})$ on day 1 at $10.30 \mathrm{~h}$ and on day 2 at $12.00 \mathrm{~h}$ (vehicle control group ). The second group $(\mathrm{P}$ alone; $\mathrm{n}=7$ ) received the vehicle injected on day 1 at $10.30 \mathrm{~h}$ and $\mathrm{P}(5 \mathrm{mg}$ in $0.1 \mathrm{ml}$ in peanut oil, sc; Eli Lilly and Co., Indianapolis, IN, USA) administered on day 2 at $12.00 \mathrm{~h}$ (P-alone group). A third group ( $\mathrm{E}$ alone; $\mathrm{n}=7$ ) was injected with estradiol-benzoate (EB, $50 \mu \mathrm{g}$ dissolved in $0.2 \mathrm{ml}$ peanut oil, sc; Sigma, St. Louis, MO, USA) on day 1 at $10.30 \mathrm{~h}$ followed by vehicle injection on day 2 at $12.00 \mathrm{~h}$. A fourth group $(\mathrm{E} / \mathrm{P} ; \mathrm{n}=7)$ was primed with $\mathrm{EB}(50 \mu \mathrm{g}$, s.c.) on day 1 at $10.30 \mathrm{~h}$ and received $\mathrm{P}(5 \mathrm{mg}$, s.c. $)$ on day 2 at $12.00 \mathrm{~h}$ (E/P-treated group). All animals were killed between 18.00 and $19.00 \mathrm{~h}$ by asphyxiation with $\mathrm{CO}_{2}$ immediately followed by decapitation. Trunk blood was collected, centrifuged, and stored at $-20^{\circ} \mathrm{C}$ until assayed for serum LH levels. The brains were rapidly removed, frozen on dry ice, and stored whole at $-80^{\circ} \mathrm{C}$.

\section{Tissue preparation}

Immediately before slicing, the brains were allowed to equilibrate in the cryostat chamber at $-20^{\circ} \mathrm{C}$. Coronal brain slices $(20 \mu \mathrm{m})$ were cut with a cryostat, thaw-mounted onto polylysine-coated slides (Fischer Scientific, Fair Lawn, NJ, USA), and stored in air-tight boxes at $-80^{\circ} \mathrm{C}$ until needed. Tissue was collected according to the rat atlas of Paxinos and Watson (50), beginning rostrally at the genu of the corpus calossum and continuing caudally $60 \mu \mathrm{m}$ beyond the decussation of the anterior commissure. The tissue slices were collected on 4 sets of slides, placing every fourth slice into a given set.

\section{$c R N A$ probe preparation}

${ }^{35}$ S-labeled galanin $c R N A$ probe. The plasmid vector Bluescript containing a cDNA complimentary to rat galanin mRNA (51) was kindly provided by Drs M. Vrontakis and Henry Friesen (University of Manitoba, Winnipeg, Canada). The plasmid consisted of a $680 \mathrm{bp}$ segment of rat galanin cDNA inserted into the EcoR1 site of Bluescript (Stratagene, San Diego, CA, USA). Hind III was used to linearize the cDNA, and the ${ }^{35} \mathrm{~S}$-labeled antisense riboprobe was generated by use of T7 RNA polymerase. The galanin probe transcription reactions had $25 \%$ of the total UTP as [35S] UTP. The final double-label hybridization solution contained a galanin cRNA probe concentration of $0.25 \mu \mathrm{g} / \mathrm{ml} \cdot \mathrm{kilobase}$.

Digoxigenin-labeled GnRH cRNA probe. A 462-base pair digoxigeninlabeled cRNA probe complementary to rat GnRH mRNA was used. The original plasmid containing the GnRH insert (52) was generously provided by Dr A. Mason (Genentech, South San Francisco, CA, USA). The probe was synthesized in vitro from linearized DNA with $400 \mu \mathrm{M}$ digoxigenin-11 uridine-5'-triphosphate (dig-11-UTP, Boehringer Mannheim, Indianapolis, IN, USA), $100 \mu \mathrm{M}$ unlabeled UTP, $500 \mu \mathrm{M}$ GTP, ATP, and CTP with SP6 RNA polymerase. Residual DNA was digested with DNAse, and the cRNA probe was separated from unincorporated nucleotides on a G-50 Sephadex column (Boehringer Mannheim, Indianapolis, IN, USA). The purified probe was diluted $1: 40$ in hybridization buffer for double-label in situ hybridization. This concentration had been determined by a test in situ hybridization assay to yield optimal binding conditions. Both probes were heat-denatured before they were added to the final hybridization buffer.

${ }^{35}$ S-labeled GnRH cRNA probe. This riboprobe was transcribed from the same plasmid used for the synthesis of the digoxigenin-labeled GnRH probe. The antisense riboprobe was transcribed in vitro from linearized DNA with $14 \%$ of the total UTP replaced with $\left[{ }^{35} \mathrm{~S}\right]$ UTP under the control of the SP6 polymerase. The final concentration of the GnRH cRNA probe in this experiment was $0.25 \mu \mathrm{g} / \mathrm{ml} \cdot$ kilobase.

The control experiments used to validate the integrity, binding kinetics, and specificity of the digoxigenin-labeled and ${ }^{35}$ S-labeled galanin probes have been previously described $(52,53)$. The specificity of the riboprobes was tested by application of sense probes, competitive administration of excess unlabeled probes with labeled probes, and pretreatment of tissue with RNAse.

\section{Double-label in situ hybridization}

The method used for double-label in situ hybridization has been published previously (53). In brief, sections were fixed in $4 \%$ paraformaldehyde and treated with $0.25 \%$ acetic anhydride in $0.1 \mathrm{M}$ triethanolamine for $10 \mathrm{~min}$. The slides were rinsed in $2 \times \operatorname{SSC}(1 \times$ salt-sodium citrate solution= $150 \mathrm{mM} \mathrm{NaCl}$ and $15 \mathrm{mM} \mathrm{Na}$ citrate), dehydrated through a graded series of ethanol, delipidated in chloroform, rehydrated in a second ethanol series, and air-dried. The tissue sections were prehybridized for $2 \mathrm{~h}$ at $60^{\circ} \mathrm{C}$ with hybridization buffer containing $2 \mathrm{mg} / \mathrm{ml}$ denatured total yeast RNA, rinsed in $2 \times$ SSC, dehydrated briefly in $70 \%$ ethanol, and air-dried. The final hybridization buffer containing both probes was applied $(60 \mu \mathrm{l} / \mathrm{slide})$ to the tissue, covered with a Parafilm coverslip and sealed with rubber cement. The slides were incubated in humid chambers overnight at $60^{\circ} \mathrm{C}$. The next day, the tissue was treated with RNAse-A and washed with increasing stringency, including a wash at $65^{\circ} \mathrm{C}$ in $0.1 \times$ SSC. Slides were then placed in $2 \times$ SSC plus $0.05 \%$ Triton X-100 containing $2 \%$ normal sheep serum (NSS) for $1 \mathrm{~h}$. They were washed in buffer $1(100 \mathrm{mM}$ Tris- $\mathrm{HCl} \mathrm{pH} 7.5,150 \mathrm{mM} \mathrm{NaCl})$ and incubated for $4 \mathrm{~h}$ at $37^{\circ} \mathrm{C}$ with anti-digoxigenin antibody fragments conjugated to alkaline phosphatase (Boehringer Mannheim, Indianapolis, IN, USA) diluted 1:1000 in buffer 1 containing 1\% NSS and 0.3\% Triton X-100. After washing, the slides were incubated in a chromagen solution for $6 \mathrm{~h}$ at $37^{\circ} \mathrm{C}$. The reaction was stopped and the slides were air-dried and stored in the dark. After overnight dry, the slides were dipped in a 3\% solution of parlodion (Fisher Scientific, Fair Lawn, NJ, USA) in isoamyl acetate, to prevent chemographic artifacts in the autoradiographic steps. The slides were air dried, dipped in Kodak NTB-2 photographic emulsion and then stored dried in light-tight boxes at $4{ }^{\circ} \mathrm{C}$. The slides were allowed to expose for 10 days, were then developed and cover-slipped.

\section{Single-label in situ Hybridization}

Following the identical protocol than for double-labeled in situ hybridization, slides were fixed in $4 \%$ paraformaldehyde, washed in phosphate buffer $\times 2$, triethanolamine with $0.25 \%$ acetic anhydride, rinsed in $2 \times \mathrm{SSC}$, dehydrated in increasing concentrations of ethanol, and delipidated in chloroform. Following $2 \mathrm{~h}$ prehybridization in hybridization buffer with transfer RNA, hybridization was carried out at $60^{\circ} \mathrm{C}$ for $18 \mathrm{~h}$ in hybridization buffer, whereby individual slides were incubated with $65 \mu 1$ medium, and covered with rubber cement-sealed Parafilm for over-night incubation. Washes in $4 \times$ SSC were followed by treatment with RNAse at $37^{\circ} \mathrm{C}$ for $30 \mathrm{~min}$, then washes of increasing stringency to $0.1 \times \mathrm{SSC}$ at $65^{\circ} \mathrm{C}$. The tissue was then dehydrated in ethanol, dipped in emulsion, and exposed for 6 days. These slides were counterstained with cresyl violet to help in identifying cells for final analysis (54).

\section{Semiquantitative analysis of cellular mRNA content}

Slides were assigned a random three letter code, and then read in random order with an automated image processing system by an operator unaware of the animal's experimental group. We determined the number of silver grains per cell using a grain counting program as previously described (53). This system consisted of a PixelGrabber video acquisition board (Perceptics Corp, Knoxville, TN, USA) attached to a Macintosh II $f x$ computer. Video images were obtained by a Dage model 65 camera 
(Dage-MTI, Inc., Michigan City, IN, USA) mounted on a Zeiss Axioskop (Zeiss, New York, NY, USA) equipped with a $40 \times$ objective, a 100 watt mercury-vapor epi-illumination light source and a polarizing filter set.

To estimate the level of galanin mRNA content in each GnRH neuron, a purple-stained digoxigenin-labeled GnRH mRNA-containing cell was first isolated under brightfield illumination. The silver grains overlying these cells were then analyzed under darkfield illumination by the image processor. Twenty-one sections per brain, equally spaced throughout the diagonal band of Broca (DBB) and preoptic area (POA). GnRH cells were identified under brightfield illumination by the presence of a dark purple-stained cell body. Single-labeled GnRH mRNA-expressing neurons were identified by the presence of a discrete grain-cluster associated with a cresyl violet stained nucleus (54)

Although the operator could subjectively estimate the number of cells that appeared to be double-labeled, we analyzed galanin mRNA signal in all identifiable GnRH neurons to avoid the subjective decision of whether a particular cell is single- or double-labeled. Similarly, grains over all GnRH neurons in the single-labeled assay were counted, to avoid potentially biased decision. The number of grains per cell is referred to here as mRNA signal level.

\section{Serum LH levels}

Serum LH levels were measured by a double-antibody radioimmunoassay with reagents obtained from the National Hormone and Pituitary Program (RP-3 standard). The intra-assay coefficient of variation was $6.4 \%$.

\section{Statistical analysis}

For all experiments, 'n' refers to the number of experimental animals within a group, and this was the ' $\mathrm{n}$ ' used in the analysis. For cellular GnRH mRNA or galanin mRNA content determinations, the mean grains per cell from individual animals were used to calculate the mean \pm SEM for each group. The differences among groups were assessed by analysis of variance (ANOVA). When the ANOVA indicated a significant difference among the groups within an experiment, Fisher's PLSD test was then used to identify significant differences between particular groups. The rejection level for statistical tests was set at $\alpha=0.05$.

\section{Acknowledgements}

The authors express their appreciation to Emilia Kabigting and Beth Tiemens for their excellent technical assistance. We thank Dr William Bremner and the laboratory staff of the Assay Core of the Population Center for Research in Reproduction at the University of Washington for performing the $\mathrm{LH}$ radioimmunoassays. This work was supported by USPHS (NIH) grants HD12652, HD12629 and HD29039 and by a Deutsche Forschungsgemeinschaft grant Ro 657/3-1

\section{Accepted 8 November 1995}

\section{References}

1. Freeman ME. (1994). The Neuroendocrine control of the ovarian cycle in the rat. In: Knobil E, Neill JD, eds. The physiology of reproduction. 2: 613-658. Raven Press, New York.

2. Pfaff DW, Schwartz-Giblin S, McCarthy MM, Kow L-M. (1994). Cellular and molecular mechanisms of female reproductive behaviors. In: Knobil E, Neill JD, ed. The Physiology of reproduction. 2: 107-220. Raven Press, New York.

3. Sarkar DK, Chiappa SA, Fink G. (1976). Gonadotropin-releasing hormone surge in proestrous rats. Nature. 264: 461-463.

4. Levine JE, Ramirez VD. (1982). Luteinizing hormone-releasing hormone release during the rat estrous cycle and after ovariectomy, as estimated with push-pull cannulae. Endocrinology. 111: 1439-1348.

5. Coen CW, Montagnese C, Opacka-Juffry J. (1990). Coexistence of gonadotrophin-releasing hormone and galanin: immunohistochemical and functional studies. J Neuroendocrinol. 2: 107-111.

6. Merchenthaler I, Lopez FJ, Negro-Vilar A. (1990). Colocalization of galanin and luteinizing hormone-releasing hormone in a subset of preoptic hypothalamic neurons: anatomical and functional correlates. Proc Natl Acad Sci USA. 87: 6326-6330.
7. Merchenthaler I. (1991). The hypophysiotropic galanin system of the rat brain. Neuroscience. 44: 643-654.

8. Marks DL, Smith MS, Vrontakis M, Clifton DK, Steiner RA. (1993). Regulation of galanin gene expression in gonadotropin-releasing hormone neurons during the estrous cycle of the rat. Endocrinology. 132: $1836-1844$.

9. Sahu A, Crowley WR, Tatemoto K, Balasubramaniam A, Kalra S P. (1987). Effects of neuropeptide Y, NPY analog (norleucine-NPY), galanin and neuropeptide $\mathrm{K}$ on LH release in ovariectomized (OVX) and OVX estrogen, progesterone treated rats. Peptides. 8: 921-926.

10. Lopez FJ, Negro-Vilar A. (1990). Galanin stimulates luteinizinghormone-releasing hormone secretion from arcuate nucleus-median eminence fragments in vitro: involvement of an alpha-adrenergic mechanism. Endocrinology. 127: 2431-2436.

11. Lopez FJ, Meade EH, Negro-Vilar A. (1993). Endogenous galanin modulates the gonadotropin and prolactin proestrous surges in the rat. Endocrinology. 132: 795-800.

12. Sahu A, Xu B, Kalra SP. (1994). Role of galanin in stimulation of pituitary luteinizing hormone secretion as revealed by a specific receptor antagonist, galantide. Endocrinology. 134: 529-536.

13. Marks DL, Lent KL, Rossmanith WG, Clifton DK, Steiner RA. (1994). Activation-dependent regulation of galanin gene expression in gonadotropin-releasing hormone neurons in the female rat. Endocrinology. 134: 1991-1998.

14. Blake CA. (1977). Effects of estrogen and progesterone on luteinizing hormone release in ovariectomized rats. Endocrinology. 101: 1122-1129.

15. McPherson JC III, Costoff A, Mahesh VB. (1975). Influence of estrogen-progesterone combinations on gonadotropin secretion in castrate female rats. Endocrinology. 97: 771-779.

16. Silverman A-J, Livne I, Witkin JW. (1994). The gonadotropinreleasing hormone $(\mathrm{GnRH})$, neuronal systems: immunocytochemistry and in situ hybridization. In: Knobil E, Neill JD, ed. The Physiology of reproduction, 2: 1683-1709. Raven Press, New York.

17. Brann DW, Chorich LP, Mahesh VB. (1993). Effect of progesterone on galanin mRNA levels in the hypothalamus and the pituitary: correlation with the gonadotropin surge. Neuroendocrinology. 58: $531-538$.

18. Marks DL, Smith MS, Clifton DK, Steiner RA. (1993). Regulation of $\mathrm{GnRH}$ and galanin gene expression in $\mathrm{GnRH}$ neurons during lactation in the rat. Endocrinology. 133: 1450-1458.

19. Rossmanith WG, Marks DL, Clifton DK, Steiner RA. (1994). Induction of galanin gene expression in gonadotropin-releasing hormone neurons with puberty in the rat. Endocrinology. 135: 1401-1408.

20. Shivers BD, Harlan RE, Morrell JI, Pfaff DW. (1983). Absence of oestradiol concentration in cell nuclei of LHRH-immunoreactive neurones. Nature. 304: 345-347.

21. Towle AC, Sze PY. (1983). Steroid binding to plasma membrane: differential binding of glucocorticoids and gonadal steroids. J Steroid Biochem. 18: 135-143.

22. Nabekura J, Oomura Y, Minami T, Mizuno Y, Fukuda A. (1986). Mechanism of the rapid effect of 17-beta-estradiol on medial amygdala neurons. Science. 233: 226-228.

23. Hua SY, Chen YZ. (1989). Membrane receptor-mediated electrophysiological effects of glucocorticoid on mammalian neurons. Endocrinology. 124: 687-691.

24. Leranth C, MacLusky NJ, Sakamoto H, Shanabrough M, Naftolin F. (1985). Glutamic acid decarboxylase-containing axons synapse on LHRH neurons in the rat medial preoptic area. Neuroendocrinology. 40: $536-539$.

25. Sar M, Sahu M, Crowley WR, Kalra SP. (1990). Localization of neuropeptide Y (NPY) immunoreactivity in estradiol concentrating cells in the hypothalamus. Endocrinology. 127: 2752-2756.

26. Lee WS, Smith MS, E. HG. (1990). Luteinizing hormone-releasing hormone neurons express fos protein during the proestrous surge of luteinizing hormone. Proc Natl Acad Sci USA 87: 5163-5167.

27. Lee WS, Abbud R, Smith MS, Hoffman GE. (1992). LHRH neurons express cJUN protein during the proestrous surge of luteinizing hormone. Endocrinology. 130: 3101-3103.

28. Lee WS, Smith MS, Hoffman GE. (1992). cFos activity identifies recruitment of luteinizing hormone releasing hormone neurons during the ascending phase of the proestrous luteinizing hormone surge. J Neuroendocrinol. 4: 161-166.

29. Kaplan LM, Hooi SC, Abraczinskas DR, Strauss RM, Davidson 
MB, Hsu DW, Koenig JI. (1990). Neuroendocrine regulation of galanin gene expression. In: Hokfelt T, Bartfai T, Jacobowitz D, Ottoson D, ed. Galanin: a multifunctional peptide in the neuro-endocrine system, 43-65. Macmillan Press, New York.

30. Anouar Y, MacArthur L, Cohen J, Iacangelo AL, Eiden LE. (1994). Identification of a TPA-responsive element mediating preferential transactivation of the galanin gene promoter in chromoffin cells. J Biol Chem. 269: 6823-6831.

31. Morgan JI, Curran T. (1991). Stimulus-transcription coupling in the nervous system: involvement of the inducible proto-oncogenes fos and jun. Annu Rev Neurosci. 14: 421-451.

32. King JC, Tai DW, Mitchell SC, Pfeiffer A, Haas P. (1995). A subgroup of LHRH neurons in guinea pigs with progestin receptors is centrally positioned within the total population of LHRH neurons. Neuroendocrinology. 61: 265-275.

33. Fox S, Harlan R, Shivers B, Pfaff DW. (1990). Chemical characterization of neuroendocrine targets for progesterone in the female rat brain and pituitary. Neuroendocrinology. 51: 276-283.

34. Olster DH, Blaustein JD. (1990). Immunocytochemical colocalization of progestin receptors and beta-endorphin or enkephalin in the hypothalamus of female guinea pigs. J Neurobiol. 21: 768-780.

35. Nielsen KH, Blaustein JD. (1990). Many progestin receptorcontaining neurons in the guinea pig ventrolateral hypothalamus contain substance P: immunocytochemical evidence. Brain Res. 517: $175-181$.

36. MacLusky NJ, McEwen BS. (1978). Oestrogen modulates progestin receptor concentrations in some rat brain regions but not in others. Nature. 274: 276-278.

37. Blaustein JD, Turcotte JC. (1989). Estradiol-induced progestin receptor immunoreactivity is found only in estrogen receptor-immunoreactive cells in guinea pig brain. Neuroendocrinology. 49: 454-461.

38. Lopez FJ, Merchenthaler I, Ching M, Wisniewski MG, Negro-Vilar A. (1991). Galanin: a hypothalamic-hypophysiotropic hormone modulating reproductive functions. Proc Natl Acad Sci USA. 88: 4508-4512.

39. Melander T, Kohler C, Nilsson S, Hokfelt T, Brodin E, Theodorsson E, Bartfai T. (1988). Autoradiographic quantitation and anatomical mapping of 125I-galanin binding sites in the rat central nervous system. J Chem Neuroanat. 1: 213-233.

40. Fisone G, Wu CF, Consolo S, Nordstrom O, Brynne N, Bartfai T, Melander T, Hokfelt T. (1987). Galanin inhibits acetylcholine release in the ventral hippocampus of the rat: histochemical, autoradiographic, in vivo, and in vitro studies. Proc Natl Acad Sci USA. 84: 7339-7343.

41. Fisone G, Bartfai T, Nilsson S, Hokfelt T. (1991). Galanin inhibits the potassium-evoked release of acetylcholine and the muscarinic receptor-mediated stimulation of phosphoinositide turnover in slices of monkey hippocampus. Brain Res. 568: 279-284.

42. Kaplan LM, Gabriel SM, Koenig JI, Sunday ME, Spindel ER,
Martin JB, Chin WW. (1988). Galanin is an estrogen-inducible, secretory product of the anterior pituitary. Proc Natl Acad Sci USA. 85: $17408-17412$.

43. O'Halloran DJ, Jones PM, Steel JH, Gon G, Giaid A, Ghatei MA, Polak JM, Bloom SR. (1990). Effect of endocrine manipulation on anterior pituitary galanin in the rat. Endocrinology. 127: 467-475.

44. Meister B, Hokfelt T. (1988). Peptide- and transmitter-containing neurons in the mediobasal hypothalamus and their relation to GABAergic systems: possible roles in control of prolactin and growth hormone secretion. Synapse. 2: 585-605.

45. Delemarre-van de Waal HA, Burton KA, Kabigting EB, Steiner RA, Clifton DK. (1994). Expression and sexual dimorphism of galanin messenger ribonucleic acid in growth hormone- releasing hormone neurons of the rat during development. Endocrinology. 134: 665-671.

46. Kim K, Lee BJ, Park Y, Cho WK. (1989). Progesterone increases messenger ribonucleic acid (mRNA) encoding luteinizing hormone releasing hormone (LHRH) level in the hypothalamus of ovariectomized estradiol-primed prepubertal rats. Brain Res Mol Brain Res. 6: $151-158$.

47. Roberts JL, Dutlow CM, Jakubowski M, Blum M, Millar RP. (1989). Estradiol stimulates preoptic area-anterior hypothalamic proGnRHGAP gene expression in ovariectomized rats. Brain Res Mol Brain Res. 6: $127-134$.

48. Rothfeld J, Hejtmancik JF, Conn PM, Pfaff DW. (1989). In situ hybridization for LHRH mRNA following estrogen treatment. Brain Res Mol Brain Res. 6: 121-125.

49. Petersen SS, McCrone S, Keller M, Shores S. (1995). Effects of estrogen and progesterone on luteinizing hormone-releasing hormone messenger ribonucleic acid levels: consideration of temporal and neuroanatomical variables. Endocrinology. 136: 3604-3610.

50. Paxinos G, Watson C. eds. (1986). The rat brain in stereotaxic coordinates. Academic Press, New York.

51. Vrontakis ME, Peden LM, Duckworth ML, Friesen HG. (1987). Isolation and characterization of a complimentary DNA (galanin) clone from estrogen-induced pituitary tumor messenger RNA. J Biol Chem. 262: 16755-16758.

52. Wiemann JN, Clifton DK, Steiner RA. (1990). Gonadotropinreleasing hormone messenger ribonucleic acid levels are unaltered with changes in the gonadal hormone milieu of the adult male rat. Endocrinology. 127: 523-532.

53. Marks DL, Wiemann JN, Burton KA, Lent KL, Clifton DK, Steiner RA. (1992). Simultaneous visualization of two cellular mRNA species by use of a new double in situ hybridization method. Mol Cell Neurosci. 3: $395-405$.

54. Wiemann JN, Clifton DK, Steiner RA. (1989). Pubertal changes in gonadotropin-releasing hormone and proopiomelanocortin gene expression in the brain of the male rat. Endocrinology. 124: 1760-1767. 